\title{
ANALISIS EFEKTIVITAS "CUSTOMER DELIGHT PROGRAM" TERHADAP MOTIVASI KERJA KARYAWAN DI SHANGRI-LA HOTEL SURABAYA
}

\author{
Rocky Hermansyah dan Eddy M. Sutanto (esutanto@peter.petra.ac.id) \\ Universitas Kristen Petra
}

\begin{abstract}
This research was taken place at Shangri-La Hotel Surabaya, an international management hotel. The population of research were 600 respondents. The purpose of this research was to understand the effectiveness of Customer Delight Program and employees' work motivation of Shangri-La Hotel Surabaya. The analysis technique used quantitative analysis. The result of research showed that there was a relationship between Customer Delight Program and employees' work motivation Shangri-La Hotel Surabaya.
\end{abstract}

Keywords: Customer Delight Program, Employees' Work Motivation, Shangri-La Hotel Surabaya, Organizational Effectiveness

\section{PENDAHULUAN}

"Seiring berjalannya waktu, banyak sekali bidang usaha baru yang bermunculan, khususnya dalam bidang usaha jasa. Salah satunya dalam usaha perhotelan. Hotel adalah suatu jenis akomodasi yang mempergunakan sebagian atau seluruh bangunannya untuk menyediakan jasa pelayanan, penginapan, makan dan minum serta jasa lainnya bagi umum yang dikelola secara komersial serta memenuhi ketentuan persyaratan yang ditetapkan di dalam keputusan pemerintah" (Sugianto 2003: 9).

Surabaya sebagai salah satu kota metropolitan di Indonesia, memiliki beberapa hotel berbintang lima. Semua berlomba-lomba untuk menarik konsumen dengan memberikan fasilitas-fasilitas dan pelayanan yang terbaik kepada konsumennya. Salah satunya adalah Shangri-La Hotel Surabaya yang dikenal sebagai hotel terbaik di Surabaya. Untuk mempertahankan predikatnya itu, Shangri-La Hotel Surabaya berupaya terus untuk meningkatkan kualitas dan mutu pelayanan serta fasilitas-fasilitasnya. Kualitas mutu pelayanan itu bergantung pada kualitas sumber daya manusianya, sebagai unsur terpenting.

Untuk mendapatkan sumber daya manusia yang berkompeten, dapat dilakukan dengan berbagai cara salah satunya bisa dilakukan dengan memberikan kompensasi pada karyawan. Akan tetapi, akan sangat sulit untuk mempertahankan motivasi kerja karyawan dalam suatu perusahaan. Untuk itu, demi tercapainya tujuan, maka suatu hotel perlu melakukan suatu program untuk meningkatkan motivasi kerja karyawan agar mampu bekerja dengan baik, dan program-program itu adalah sebagai berikut: "memberikan gaji atau upah yang sesuai, lapangan pekerjaan yang aman, suasana kerja yang kondusif, kesempatan untuk maju, organisasi pekerjaan yang dihargai oleh masyarakat, pimpinan yang adil dan bijaksana dan pengarahan dan perintah yang wajar serta pemberian penghargaan terhadap pekerjaan yang telah dilakukan" (Ranupandjojo dan Husnan 2004: 194). Diketahui dari penelitian sebelumnya bahwa tingkat motivasi kerja karyawan di Shangri-La Hotel Surabaya tinggi. Hal tersebut diketahui terdapat keterkaitan antara keberadaan Shangri-La Academy Program dengan tingkat motivasi kerja karyawan ShangriLa Hotel Surabaya (Fandianto dan Sutanto 2012).

Seperti yang diketahui bahwa kemampuan kerja seseorang itu sangat terbatas di mana banyak faktor yang membatasi kegiatan manusia, antara lain fisik, daya pikir, pendidikan 


\section{Rocky Hermansyah \\ Eddy M. Sutanto}

dan latihan, sikap, waktu, dan tempat. Untuk itu perlu adanya faktor pendorong melalui teknik-teknik tertentu agar motivasi kerja dapat dipertahankan bahkan ditingkatkan. Mempertahankan motivasi kerja bagi setiap individu tidaklah mudah, mengingat bahwa setiap individu yang bekerja mempunyai tujuan yang berbeda-beda dan mungkin bertentangan dengan tujuan perusahaan. Jika hal ini terjadi, maka diperlukan teknik-teknik motivasi tertentu untuk dapat menyelaraskan tujuan perusahaan dengan masing-masing individu. Apabila seorang manajer telah mengetahui teknik motivasi yang tepat dan yang harus diberikan kepada karyawannya, maka motivasi kerja karyawannya akan meningkat dan hal ini akan berdampak positif pada produktivitas karyawan.

Hal tersebut juga yang dilakukan oleh pihak Human Resources Shangri-La Hotel Surabaya untuk meningkatkan motivasi kerja karyawannya. Menurut wawancara dengan salah satu karyawan Human Resources Shangri-La Hotel Surabaya. Human Resources Department Shangri-La Hotel Surabaya merasa bahwa produktivitas kerja karyawan agak menurun. Untuk lebih meningkatkan motivasi karyawan operasional di Shangri-La Hotel Surabaya, Human Resource Department membuat suatu program. Program ini dinamakan Customer Delight Program atau CDP.

Program CDP ini merupakan program yang dilakukan oleh Human Resource Department Shangri-La Hotel Surabaya untuk meningkatkan motivasi kerja agar dapat bekerja lebih baik lagi dari sebelumnya. Program ini dilakukan pertama kalinya pada tahun 2006. CDP diberikan setiap 1 bulan sekali pada seluruh karyawan ataupun trainee yang melakukan sesuatu hal yang dapat membahagiakan tamu, sesama karyawan, dan kepada karyawan atau trainee yang memberikan usulan-usulan baru yang dapat memperlancar operasional hotel.

Dalam wawancara langsung yang dilakukan kepada karyawan yang pernah mendapatkan CDP. Setelah mendapat CDP Silver Level, semakin termotivasi untuk bekerja lebih baik lagi untuk mendapatkan CDP Gold Level. Namun, dalam suatu wawancara lainnya dengan salah satu dari karyawan Shangri-La Hotel Surabaya yang pernah mendapatkan CDP. Karyawan itu mengatakan bahwa dia tidak termotivasi untuk bekerja dengan baik guna mendapatkan level yang lebih tinggi.

Oleh karena itu, dalam usaha mengetahui lebih jauh lagi tentang efektivitas dalam pemberian CDP terhadap motivasi kerja karyawan di Shangri-La Hotel Surabaya, maka dalam penelitian ini ditetapkan dua rumusan masalah, sebagai berikut: Bagaimana tingkat efektivitas pemberian program CDP terhadap motivasi kerja karyawan di Shangri-La Hotel Surabaya? Apakah ada perbedaan tingkat motivasi kerja karyawan Shangri-La Hotel Surabaya antara yang sudah menerima CDP dengan karyawan yang belum pernah menerima CDP? Penelitian ini dilakukan hanya pada karyawan ataupun trainee yang bekerja di departemen front office. Hal ini dengan pertimbangan bahwa departemen ini memiliki peran yang strategis bagi keberadaan suatu hotel.

\section{LANDASAN TEORI DAN PENGEMBANGAN HIPOTESIS}

Konsep customer delight program dan teori motivasi kerja digunakan untuk melandasi penelitian ini. Secara lebih mendetail keduanya dijabarkan berikut itu.

\section{Teori Efektivitas}

Pengertian efektivitas secara umum menunjukkan sampai seberapa jauh tercapainya suatu tujuan yang terlebih dahulu ditentukan. Sastradipoera (2004; Mangkunegara 2004) juga mengungkapkan bahwa efektivitas adalah "suatu keadaan yang menunjukkan tingkat keberhasilan kegiatan manajemen dalam mencapai tujuan yang telah ditetapkan terlebih dahulu". Menurut Robbins (2009) adalah "efektivitas sering dideskripsikan sebagai "melakukan sesuatu dengan tepat" kegiatan kerja yang akan membantu organisasi 
mencapai tujuannya". Schemerhorn (2001) menjelaskan efektivitas adalah "pencapaian target output yang diukur dengan cara membandingkan output anggaran atau seharusnya (OA) dengan output realisasi atau sesungguhnya (OS), jika (OA) > (OS) disebut efektif".

Siagian (2000: 32) mengungkapkan beberapa hal yang menjadi kriteria dalam pengukuran efektivitas dapat diukur dari berbagai hal, yaitu: "kejelasan tujuan yang hendak dicapai, kejelasan strategi pencapaian tujuan, proses analisa dan perumusan kebijakan yang mantap, perencanaan yang matang, penyusunan program yang tepat, tersedianya sarana dan prasarana kerja, pelaksanaan yang efektif dan efisien, sistem pengawasan dan pengendalian yang mendidik". Dari pengertian-pengertian efektivitas tersebut dapat disimpulkan bahwa efektivitas adalah suatu ukuran yang menyatakan seberapa jauh target (kuantitas, kualitas dan waktu) yang telah dicapai oleh manajemen, yang mana target tersebut sudah ditentukan terlebih dahulu.

\section{Customer Delight Program}

Menurut data-data dari bagian Human Resources Shangri-La Hotel Surabaya, Customer Delight Program (CDP) merupakan suatu program kompensasi yang dibuat oleh Shangri-La Hotel International untuk memberi penghargaan kepada karyawannya yang telah bekerja dengan baik dan melebihi apa yang diharapkan oleh perusahaan. Program ini mulai diterapkan di Shangri-La Hotel Surabaya mulai tahun 2006. Penghargaan itu sendiri adalah sebuah bentuk dari kompensasi yaitu apresiasi kepada suatu prestasi tertentu yang diberikan baik oleh perorangan ataupun suatu lembaga. Penghargaan dapat berupa materi ataupun non materi, namun tetap memberikan kebanggaan bagi siapa saja yang menerimanya.

Customer Delight Program (CDP) itu sendiri termasuk dalam bentuk kompensasi baik finansial maupun non finansial. Bentuk finansial secara langsung, yaitu bonus dan non finansial sebagai pengakuan atas prestasi yang telah dicapai oleh seorang karyawan. Untuk mendapatkan CDP, seorang karyawan harus bekerja dengan baik untuk mendapatkan pujian dari tamu, mendapat pujian dari sesama karyawan maupun dari supervisor. Semua itu, akan dikirim ke departemen HRD yang kemudian akan menjadi nominasi-nominasi dari CDP. Akhirnya pihak HRD akan menilai nominasi mana yang layak menjadi pemenang dari program CDP tersebut, dan dari tiap - tiap departemen akan dipilih beberapa pemenang.

Adapun tingkatan-tingkatan Customer Delight Program (CDP) adalah sebagai Silver Level, yaitu: tingkatan pertama dalam pemberian CDP. Dalam tingkatan ini seorang karyawan akan mendapatkan sertifikat dan hadiah berupa souvenir, seperti: tas, mug dan topi. Gold Level, yaitu tingkatan kedua, karyawan akan mencapai tingkatan ini apabila ia telah mendapatkan Silver Level selama 3 kali berturut-turut. Karyawan akan mendapatkan sertifikat Gold Level dan hadiah berupa uang tunai senilai Rp 300.000. Diamond Level, didapatkan apabila karyawan telah memperoleh Gold Level selama 3 kali berurut-turut. Sama seperti tingkatan-tingkatan yang lain, pada Diamond Level akan mendapat sertifikat dan vang tunai sebesar Rp 800.000.

CDP ini merupakan program global yang digalakkan oleh management Shangri-La international. Program ini secara teknis diserahkan kepada jajaran management di lokasi di mana hotel Shangri-La itu berada. kriteria untuk masuk dalam nominasi CDP ini berdasarkan penilaian langsung management yang diwakili oleh pejabat setingkat supervisor sampai kepada General Manager. Adapun penentuan kriteria nominator penerima CDP berdasarkan pada pertimbangan-pertimbangan berikut: Good Things I hear form, formulir ini terdapat di seluruh area pelayanan Hotel Shangri-La mulai dari area kamar, restoran, meja resepsionis dan area-area strategis yang lain. Formulir ini diisi oleh tamu berisi tentang layanan istimewa yang dikenali tamu. Formulir ini secara reguler akan dikumpulkan setiap minggu sekali dan akan di serahkan kepada pihak Human Resources untuk dilakukan 


\section{Rocky Hermansyah Eddy M. Sutanto}

validasi hasil validasi akan diserahkan di forum management morning briefing untuk pengesahan orang-orang yang mendapat penghargaan CDP ini. Misalnya seperti seorang tamu yang merasa puas setelah dengan tulus dilayani oleh staff guest relation ketika mengantar ke kamar, maka tamu akan menuliskan perasaan puasnya dalam formulir ini. Department Head Book Note, Book note ini sendiri berisi rekomendasi-rekomendasi dari manager atau kepala bagian bahwa karyawan nya telah layak menerima CDP dan nantinya akan dikirimkan ke pihak Human Resources. Book Note itu sendiri hanya terdapat di meja-meja para manager dan kepala bagian. Misalnya seperti seorang kepala bagian restoran melihat salah satu anak buahnya melakukan extramile yakni bersedia memperpanjang shift nya ketika restoran dalam posisi ramai oleh tamu, sehingga kepala bagian tadi memberikan komentar positif nya ke dalam book note dan menyerahkan nya pada pihak Human Resources sebagai bahan rekomendasi sebaai nominator penerima penghargaan CDP. Customer Delight program pad, sebuah bendel catatan yang diberikan kepada karyawan setingkat supervisor sampai pada manajer lini yang mana berguna sebagai media untuk memberikan recognition kepada kryawan-karyawan yang dengan tulus melakukan do more atau extramile, misalnya seorang supervisor yang terkesan dengan ketekunan seorang staffnya dalam melakukan kegiatan dan pekerjaannya.

Berdasarkan wawancara dengan pihak Human Resources Shangri-La Hotel mengatakan bahwa General Manager menyarankan dalam satu hari dari setiap department harus memberikan sebanyak minimal 10 CDP kepada karyawan atau trainee nya, dan yang nantinya dikirimkan ke pihak Human Resources, dan akan disaring lagi oleh pihak Human Resources untuk dinilai apakah benar-benar layak karyawan atau trainee tersebut untuk diberikan CDP.

Untuk mendapatkan CDP itu sendiri pihak management Shangri-La mempunyai kriteria sebagai berikut: bagi karyawan atau trainee yang Do more/ Extramile, misalnya seperti overtime pada jam kerja nya atau melebihi jam kerja yang ditentukan oleh Shangri-La tanpa ada paksaan dari manager atau supervisor, karyawan itu akan diberikan CDP. Hal itu karena telah membuat manager menjadi terkesan oleh pekerjaan yang telah dilakukannya. Komentar dari tamu, berdasarkan studi observasi yang dilakukan ada beberapa tamu yang merasa bahagia dan puas selama menginap di Shangri-La Hotel dan tamu tersebut akan menulis email kepada pihak management Shangri-La ataupun dipublikasikan bahwa dia merasa puas dengan pelayanan yang diberikan kepadanya, dan pihak management Shangri-La akan mencari tahu siapa karyawan yang melayani tamu tersebut, sehingga merasa bahagia dan puas selama menginap di Shangri-La untuk diberikan CDP. Misalkan ada tamu yang kehilangan dompetnya dan ditemukan oleh karyawan atau trainee tanpa sepengetahuan dari manager dia mengembalikan dompet tamu tersebut tanpa kurang dari apapun, maka tamu tersebut merasa puas dengan pelayanan yang diberikan dan tamu tersebut menulis email kepada pihak Shangri-La, maka pihak Human Resources Department akan mencari tahu siapa karyawan atau trainee yang telah menemukan dompet tersebut untuk diberikannya CDP.

Setiap bulan bagi karyawan atau trainee yang menerima CDP akan dipublikasikan di notice board dan bisa dibaca banyak orang dan hal ini akan membuat karyawan atau trainee merasa bangga bahwa dirinya telah menerima CDP. Notice board itu sendiri ditempatkan di lorong tempat keluar masuknya karyawan atau trainee Shangri-La Hotel dan ini menjadikan bisa dibaca oleh semua staff Shangri-La Hotel Surabaya. Program CDP itu sendiri merupakan program "recognition" karena CDP merupakan program pengenalan untuk lebih mengenal satu sama lain staff nya. Setiap bulan nya bagi semua karyawan atau trainee yang telah menerima CDP akan diadakan acara gathering untuk penerimaan sertifikat CDP, pada acara gathering tersebut akan dihadiri oleh General Manager ShangriLa Hotel untuk menyerahkan sertifikat CDP. Pada acara gathering tersebut juga diadakan game-game untuk lebih memeriahkan suasana dan mendekatkan staff satu sama lain. Pada akhir acara akan diadakan makan bersama seluruh staff Shangri-La Hotel yang menghadiri acara gathering tersebut. 
Menurut Luthans (2006; Simamora 2003), pemberian kompensasi dalam suatu organisasi harus diatur sedemikian rupa sehingga merupakan sistem yang baik dalam organisasi. Dengan sistem yang baik ini akan dicapai beberapa tujuan organisasi, yaitu: Menghargai prestasi kerja. Dengan pemberian kompensasi yang memadai adalah suatu penghargaan organisasi terhadap prestasi kerja para karyawannya. Selanjutnya akan mendorong perilaku-perilaku atau performance karyawan sesuai yang diinginkan organisasi; Menjamin keadilan. Dengan adanya sistem kompensasi yang baik akan menjamin terjadinya keadilan di antara karyawan dalam organisasi. Masing-masing karyawan akan memperoleh imbalan yang sesuai dengan tugas, fungsi, jabatan, dan prestasi kerjanya; Mempertahankan karyawan. Dengan sistem kompensasi yang baik, para karyawan akan betah atau bertahan bekerja pada organisasi itu. Hal ini berarti mencegah seorang karyawan keluar dari organisasi itu untuk mencari pekerjaan yang lebih baik; Memperoleh karyawan yang bermutu. Dengan memperoleh kompensasi yang baik dan menarik lebih banyak calon karyawan. Dengan banyaknya pelamar atau calon akan lebih banyak mempunyai peluang untuk memilih karyawan yang bermutu tinggi; Pengendalian biaya. Dengan sistem pemberian kompensasi yang baik, akan mengurangi seringnya melakukan recruitment, sebagai akibat dari makin seringnya karyawan yang keluar mencari pekerjaan yang lebih menguntungkan. Hal ini berarti penghematan biaya untuk recruitment dan seleksi calon karyawan baru; Memenuhi peraturan-peraturan. Sistem administrasi kompensasi yang baik merupakan tuntutan dari pemerintah (hukum). Suatu organisasi yang baik dituntut adanya sistem administrasi kompensasi yang baik pula (Dessler 2011; Milkovich dan Newman 2005).

\section{Motivasi Kerja}

Motivasi kerja dapat didefinisikan sebagai suatu dorongan secara psikologis kepada seseorang yang menentukan arah dari perilaku (direction of behavior) seseorang dalam suatu organisasi, tingkat usaha (level of effort), dan tingkat kegigihan atau ketahanan dalam menghadapi suatu halangan atau masalah (level of persistence) (George dan Jones 2005). George dan Jones (2005: 175) menyatakan bahwa unsur-unsur motivasi kerja adalah sebagai berikut: Arah perilaku (direction of behavior). Di dalam bekerja, ada banyak perilaku yang dapat dilakukan oleh karyawan. Arah perilaku (direction of behavior) mengacu pada perilaku yang dipilih seseorang dalam bekerja dari banyak pilihan perilaku yang dapat mereka jalankan baik tepat maupun tidak. Banyak contoh perilaku tidak tepat yang dapat dilakukan oleh seorang karyawan, perilaku-perilaku ini nantinya akan menjadi suatu penghambat bagi organisasi dalam mencapai tujuannya. Untuk mencapai tujuan perusahaan secara maksimal, karyawan harus memiliki motivasi untuk memilih perilaku yang fungsional dan dapat membantu organisasi dalam mencapai tujuannya. Setiap karyawan diharapkan dapat bekerja tepat waktu, mengikuti peraturan yang berlaku, serta kooperatif dengan sesama rekan kerja. Tingkat Usaha (level of effort). Tingkat usaha atau level of effort berbicara mengenai seberapa keras usaha seseorang untuk bekerja sesuai dengan perilaku yang dipilih. Dalam bekerja, seorang karyawan tidak cukup jika hanya memilih arah perilaku yang fungsional bagi pencapaian tujuan perusahaan. Namun, juga harus memiliki motivasi untuk bekerja keras dalam menjalankan perilaku yang dipilih. Misalnya dalam pekerjaan, seorang pekerja tidak cukup hanya memilih untuk selalu hadir tepat waktu, namun juga perlu dilihat keseriusan dan kesungguhannya dalam bekerja. Tingkat kegigihan (level of persistence). Hal ini mengacu pada motivasi karyawan ketika dihadapkan pada suatu masalah, rintangan atau halangan dalam bekerja, seberapa keras seorang karyawan tersebut terus berusaha untuk mrnjalankan perilaku yang dipilih. Misalnya saja bila ada kendala pada cuaca atau masalah kesehatan seorang karyawan produksi, apakah karyawan tersebut tetap tepat waktu masuk bekerja dan sungguh-sungguh mengerjakan tugas seperti biasanya atau memilih hal lain, seperti ijin pulang atau tidak masuk kerja. Dalam hal ini dibuat pengecualian jika masalah kesehatan yang dialami pekerja termasuk penyakit serius yang dapat menyebabkan seseorang tidak mampu bekerja. 
Motivasi kerja dapat dipengaruhi oleh beberapa faktor sebagaimana terlihat dalam Gambar 1 di bawah ini:

Gambar 1. Faktor yang Mempengaruhi Motivasi Kerja

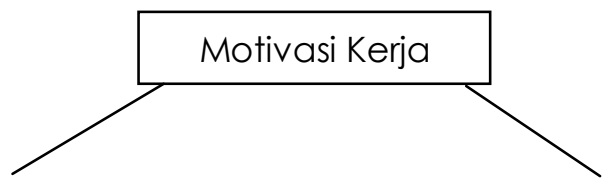

\begin{tabular}{|l|}
\hline Faktor Eksternal: \\
- Peraturan yang \\
berlaku \\
- Supervisi yang \\
baik \\
- Lingkungan \\
kerja yang \\
menyenangkan \\
- Kompensasi \\
yang memadai \\
- Adanya \\
penghargaan \\
atau prestasi
\end{tabular}

Faktor Internal:

- Kematangan

pribadi

- Keinginan dan

harapan

pribadi

- Tingkat

pendidikan

- Kebutuhan

- Kelelahan dan

kebosanan

- Kepuasan kerja

Sumber : Saydam (2006: 258)

Kerangka Pemikiran Penelitian

Kerangka pemikiran diperlukan sebagai acuan berpikir untuk memudahkan pembaca untuk mengetahui apa sesungguhnya yang dibahas pada penelitian ini. Kerangka pemikiran yang digunakan dalam penelitian ini adalah sebagai berikut:

\section{Gambar 2. Kerangka Pemikiran Penelitian}

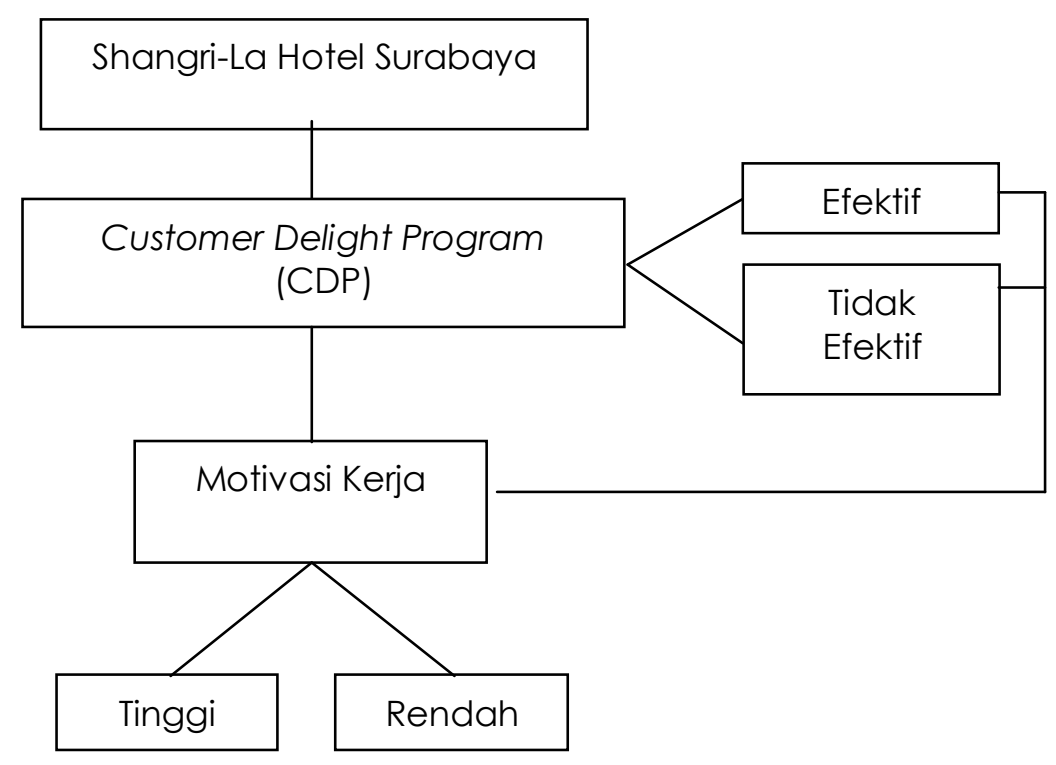

Shangri-La Hotel Surabaya memiliki program kompensasi, salah satunya adalah program Customer Delight Program (CDP). Apabila CDP itu efektif, maka motivasi kerja karyawan 
akan tinggi, namun apabila program CDP tidak efektif, maka motivasi kerja karyawan Shangri-La Hotel Surabaya rendah.

\section{Hipotesis Penelitian}

Dalam penelitian ini, Customer Delight Program (CDP) sebagai salah satu bentuk dari kompensasi, baik finansial (berupa pemberian souvenir maupun uang) maupun non finansial (berupa pemberian penghargaan atas prestasi kerja karyawan) merupakan salah satu alat yang dapat meningkatkan motivasi kerja karyawan. Hal ini didukung oleh penuturan beberapa ahli, yaitu: Menurut Bernardin (2010; Becker et al. 2001; Lawler 2002; Rynes dan Bono 2000) "Diyakini bahwa imbalan akan memotivasi prestasi, ...imbalan akan dipakai sebagai dorongan atau motivasi pada suatu tingkat perilaku dan prestasi, dan dorongan pemilihan organisasi sebagai tempat bekerja". Menurut Cascio (2005: 429) "The desire to obtain additional recognition can become a powerful need that employees strive to fulfil". Dalam hal ini, keinginan untuk mendapat penghargaan tambahan dapat menjadi kebutuhan yang kuat di mana karyawan akan berusaha untuk memenuhinya, salah satunya dengan giat bekerja. Berdasar rumusan masalah dan kerangka penelitian, maka hipotesis dalam penelitian ini, antara lain: $\mathrm{H} \mathrm{l}$, diduga pemberian CDP efektif dalam meningkatkan motivasi kerja karyawan Shangri-La Hotel Surabaya. H2, diduga ada perbedaan motivasi kerja karyawan Shangri-La Hotel Surabaya antara yang sudah menerima CDP dengan yang belum menerima CDP.

\section{METODE PENELITIAN}

Jenis penelitian yang akan digunakan dalam penelitian ini adalah penelitian kuantitatif, di mana akan dibahas dan dipaparkan pengaruh dari pemberian CDP terhadap motivasi kerja karyawan Shangri-La Hotel dengan cara melakukan wawancara dan membagikan kuesioner.

Populasi adalah sekumpulan orang atau obyek yang memiliki kesamaan dalam satu atau beberapa hal dan membentuk masalah pokok dalam suatu riset khusus (Santoso 2001: 79). Populasi penelitian ini adalah semua karyawan dan trainee Shangri-la Hotel Surabaya yang berjumlah 600 orang. Hal ini dimaksudkan agar responden benar-benar mengerti mengenai Shangri-La Hotel dan prosedur-prosedur di dalamnya. Sampel adalah bagian atau sejumlah cuplikan tertentu yang diambil dari suatu populasi atau diteliti secara rinci (Sugiyono 2004). Sampel yang diambil dalam penelitian ini adalah karyawan dan trainee yang bekerja di Shangri-La Hotel pada bagian Front Office yang berjumlah 50 orang. Sampel dalam penelitian ini dibatasi jumlahnya karena pihak Human Resources Department memberikan batasan kepada peneliti mengingat kesibukan dari karyawan Shangri-La Hotel itu sendiri.

Teknik pengambilan sampel adalah non-probability sampling di mana penarikan sampel tidak penuh dilakukan dengan menggunakan hukum probabilitas, artinya bahwa tidak semua unit yang berada dalam populasi memiliki kesempatan yang sama untuk dijadikan sampel dalam penelitian (Kuncoro 2004). Selain itu juga ditentukan dengan teknik judgemental sampling, di mana sampel yang dipilih dianggap sebagai pihak yang paling baik untuk memberikan informasi dan mendapatkan data - data yang diperlukan selama penelitian.

Dalam penentuan sampel penelitian, ditetapkan beberapa kriteria, diantaranya: Karyawan berada dalam satu departemen, yaitu Front Office. Karyawan telah bekerja di Shangri-La Hotel selama lebih dari satu tahun dan trainee yang bekerja selama masa trainee nya. Jadi di dalam penelitian ini, disebarkan kuesioner kepada 50 orang sebagai sampel.

Adapun variabel-variabel yang diteliti, antara lain: Sikap karyawan terhadap CDP (X), yaitu: tanggapan karyawan dan trainee terhadap adanya program Customer Delight Program 


\section{Rocky Hermansyah \\ Eddy M. Sutanto}

yang diberikan oleh Shangri-La Hotel Surabaya. Sikap karyawan terhadap CDP diukur menggunakan skala likert dengan empat pilihan jawaban. Kemudian ditentukan batasanbatasan, sebagai berikut:

- Kategori penilaian sikap karyawan terhadap CDP positif apabila skor 2,71-4,00

- Kategori penilaian sikap karyawan terhadap CDP negatif apabila skor 1,50-2,70 Indikator dari variabel ini, antara lain:

a. Sikap karyawan dan trainee yang pernah menerima CDP.

- Kepentingan program CDP $\left(X_{1}\right)$, merupakan sikap karyawan dalam menilai tingkat kepentingan program CDP di Shangri-La Hotel Surabaya.

- Kesan terhadap CDP $\left(\mathrm{X}_{2}\right)$, penilaian yang diberikan oleh karyawan atas berjalannya program CDP.

- Kepuasan atas CDP $\left(X_{3}\right)$, yaitu suatu perasaan puas seorang karyawan terhadap CDP yang telah diraihnya.

- Tantangan dalam CDP $\left(X_{4}\right)$, yakni tanggapan mengenai tantangan seorang karyawan dalam mencapai level yang lebih tinggi dalam CDP.

- Hubungan dengan motivasi kerja $\left(\mathrm{X}_{5}\right)$, merupakan sikap karyawan setelah menerima CDP berhubungan dengan motivasi kerja.

- Insentif dalam CDP $\left(X_{6}\right)$, menilai insentif yang diberikan dalam program CDP sudah memuaskan atau belum.

- Uang dalam CDP $\left(\mathrm{X}_{7}\right)$, menilai uang yang diberikan dalam program CDP dianggap sudah mencukupi atau belum.

b. Sikap karyawan dan trainee yang belum pernah menerima CDP. Indikatornya sama dengan sikap karyawan dan trainee yang sudah menerima

CDP, tetapi ada beberapa indikator yang tidak disertakan, yaitu: $X_{3}$ dan $X_{5}$.

Variabel yang kedua ialah motivasi kerja karyawan (Y), yaitu: dorongan yang ada dalam diri seseorang yang menggerakkan, mengarahkan perilakunya untuk memenuhi tujuan tertentu. Motivasi kerja karyawan, diukur dengan menggunakan skala likert, dengan empat pilihan jawaban yang dapat dipilih oleh reponden. Selanjutnya akan ditentukan batasan- batasan dengan kriteria sebagai berikut :

- Kategori penilaian motivasi kerja tinggi bila skor antara 2,71-4,00

- Kategori penilaian motivasi kerja rendah bila skor antara 1,50-2,70

Untuk indikator motivasi kerja, berdasarkan pada tiga unsur-unsur motivasi kerja menurut George dan Jones (2005: 175), meliputi:

a. Arah perilaku (direction of behavior): menyatakan perilaku atau ketaatan yang dipilih oleh karyawan dalam melaksanakan tugas dan pekerjaan.

- Kehadiran $\left(Y_{1}\right)$, merupakan tingkat kehadiran seorang karyawan Shangri-La hotel Surabaya dalam bekerja.

- Ketepatan waktu $\left(Y_{2}\right)$, merupakan kebiasaan perilaku karyawan datang tepat waktu dalam bekerja

- Menaati peraturan (Y $\left.Y_{3}\right)$, merupakan tindakan seorang karyawan untuk menaati peraturan-peraturan tang berlaku dalam perusahaan.

- Hubungan dengan rekan kerja $\left(Y_{4}\right)$, yaitu perilaku karyawan dengan sesama rekan kerjanya.

b. Tingkat usaha (level of effort): menyatakan tingkat usaha dan keseriusan karyawan dalam melaksanakan tugas dan pekerjaan.

- Memanfaatkan waktu dengan efektif $\left(Y_{5}\right)$, yakni perilaku karyawan yang selalu berusaha sebaik mungkin memanfaatkan karyawan pada jam kerja.

- Ketrampilan $\left(Y_{6}\right)$, yaitu usaha seorang karyawan untuk melakukan pekerjaan dengan terampil dan kreatif.

- Ketelitian dalam bekerja $\left(Y_{7}\right)$, yaitu usaha seorang karyawan untuk tidak melakukan kesalahan dalam bekerja.

- Kesungguhan dalam bekerja (Y8), merupakan usaha dari karyawan untuk serius dalam bekerja.

c. Tingkat kegigihan (level of presistence) menyatakan tingkat kegigihan karyawan dalam menghadapi rintangan dalam melaksanakan tugas dan pekerjaan. 
- Pantang menyerah $\left(Y_{9}\right)$, merupakan perilaku karyawan untuk memperbaiki kesalahan yang dilakukannya.

- Tidak mudah putus asa (Y10), yaitu perilaku karyawan apabila mendapat teguran dari atasannya tidak putus asa, tetapi semakin termotivasi untuk bekerja lebih baik.

- Ketekunan $\left(Y_{11}\right)$, merupakan tindakan seorang karyawan walaupun dalam keadaan apapun tetap masuk kerja seperti biasa.

- Kestabilan dalam bekerja $\left(Y_{12}\right)$, dimana suatu usaha perilaku karyawan untuk menghasilkan pekerjaan sesuai dengan standar.

Variabel yang ketiga ialah efektivitas CDP. Customer Delight Program merupakan salah satu program kompensasi finansial dan non finansial Shangri-La Hotel Surabaya. Penilaian efektivitas CDP adalah sebagai berikut: CDP efektif, apabila sikap karyawan terhadap CDP positif dan motivasi kerja tinggi. CDP tidak efektif, apabila sikap karyawan terhadap CDP positif dan motivasi kerja rendah atau sikap karyawan terhadap CDP negatif dan motivasi kerja tinggi.

\section{Uji Validitas}

Uji validitas dilakukan pada saat pre test yang diberikan pada 30 orang. Pre test diberikan pada 30 orang responden yang merupakan karyawan dan trainee Shangri-La Hotel Surabaya pada tanggal 21 Mei 2010. Uji validitas ini diolah dengan korelasi product moment atau pearson dengan bantuan SPSS. Bila nilai $p<0,03$ berarti data tersebut signifikan. Bila dengan rumus korelasi product moment $(r)$ maka bentuk keputusannya rhitung $\geq$ rtabel berarti signifikan yang berarti bahwa butir pernyataan valid. Hasil uji validitas dalam penelitian ini menunjukkan bahwa seluruh pernyataan dalam kuesioner dinyatakan valid (Santoso 2001).

\section{Uji Reliabilitas}

Reliabilitas atau keterandalan ialah indeks yang menunjukkan sejauh mana suatu alat ukur dapat dipercaya atau dapat diandalkan. Hal ini berarti menunjukkan sejauh mana hasil pengukuran tersebut tetap konsisten jika dilakukan pengukuran dua kali atau lebih terhadap gejala yang sama. Pengujian reliabilitas ini akan dikatakan reliabel apabila nilai $r \geq 0,06$. Hasil reliabilitas dengan menyebar kuesioner kepada 30 orang responden menunjukkan bahwa terandal (Santoso 2001).

\section{HASIL DAN PEMBAHASAN}

\section{Deskripsi Sikap Karyawan terhadap Customer Delight Program}

Sikap karyawan terhadap CDP, diukur dengan kategori positif dan negatif. Apabila sikap karyawan terhadap CDP positif berarti karyawan menganggap bahwa CDP tersebut penting, begitu pula sebaliknya apabila sikap karyawan terhadap CDP negatif, berarti karyawan tidak menganggap CDP tersebut penting. Hasil pengelompokan sikap karyawan terhadap CDP berdasarkan pada distribusi dua tingkatan sikap karyawan terhadap CDP tersebut adalah sebanyak 29 orang atau 58\% dari seluruh jumlah karyawan dan trainee yang menjadi responden memiliki sikap positif terhadap CDP, sedangkan 21 orang sisanya atau $42 \%$ memiliki sikap negatif terhadap CDP. Dari data tersebut, dapat disimpulkan bahwa sikap dari sebagian besar karyawan dan trainee Shangri-La Hotel Surabaya terhadap CDP adalah positif.

\section{Deskripsi Motivasi Kerja Karyawan}

Berdasarkan pada nilai rata-rata pernyataan motivasi kerja karyawan, terlihat bahwa pernyataan mengenai usaha untuk tidak melakukan kesalahan dalam bekerja menempati nilai rata-rata tertinggi sedangkan nilai terendah adalah pertanyaan mengenai tingkat 
Rocky Hermansyah
Eddy M. Sutanto

kehadiran karyawan. Rata-rata nilai motivasi kerja tiap karyawan adalah 48 orang karyawan atau $96 \%$ memiliki tingkat motivasi kerja yang tinggi, sedangkan 2 orang sisanya atau hanya $4 \%$ menunjukkan tingkat motivasi kerja yang negatif. Hal tersebut menunjukkan bahwa sebagian besar karyawan dan trainee Shangri-La Hotel Surabaya bahwa memiliki motivasi kerja yang tinggi.

Efektivitas Customer Delight Program

Untuk menilai efektivitas dari pemberian CDP, penulis menggunakan persentase dari sikap karyawan terhadap CDP dan tingkat motivasi kerja karyawan. Penilaian efektivitas CDP adalah sebagai berikut :

a. CDP efektif, apabila:

- sikap karyawan terhadap CDP positif dan motivasi kerja tinggi.

b. CDP tidak efektif, apabila:

- sikap karyawan terhadap CDP positif dan motivasi kerja rendah, atau

- sikap karyawan terhadap CDP negatif dan motivasi kerja tinggi.

Berdasarkan distribusi penilaian efektivitas CDP dengan kriteria yang ditetapkan, maka hipotesis satu $(\mathrm{H} 1)$ terbukti yaitu pemberian CDP efektif dalam meningkatkan motivasi kerja karyawan Shangri-La Hotel Surabaya. Hal tersebut didukung data hasil penelitian yang menunjukkan persentase bahwa CDP tersebut efektif sebesar 56\%. Namun demikian, yang menyatakan tidak efektif cukup besar, yaitu sebesar $44 \%$.

\section{Analisis Regresi Linier Sederhana}

Untuk keperluan pengujian hipotesis penelitian kedua (H2), maka data-data kemudian diolah dengan menggunakan teknik regresi linier sederhana. Berikut adalah tabel yang memaparkan kekuatan hubungan antar variabel serta pengaruh variabel independen terhadap variabel dependen secara bersama-sama.

Tabel 1. Koefisien Korelasi (R) dan Determinasi ( $\left.\mathrm{R}^{2}\right)$

\begin{tabular}{|c|c|c|c|c|}
\hline $\begin{array}{c}\text { Mode } \\
\mathrm{I}\end{array}$ & $\mathrm{R}$ & $\mathrm{R} 2$ & $\begin{array}{c}\text { Adjusted } \\
\mathrm{R} 2\end{array}$ & $\begin{array}{c}\text { Std. Error of } \\
\text { the } \\
\text { Estimate }\end{array}$ \\
\hline 1 & $.505(\mathrm{a})$ & .255 & .239 & .31189 \\
\hline
\end{tabular}

a Predictors: (Constant), CDP

b. Dependent Variable: Motivasi Kerja Karyawan

Sumber : Hasil pengolahan data kuesioner

Pada hasil $\mathrm{R}^{2}$ diperoleh angka 0,255 . Hal ini dapat diartikan bahwa besarnya persentase nilai variabel independen (sikap karyawan terhadap Customer Delight Program) untuk menjelaskan variabel dependen (motivasi kerja karyawan) adalah sebesar 25.5\%, sedangkan sisanya $74.5 \%$ dijelaskan oleh variabel lain di luar variabel yang diteliti. Tabel 2 berikut ini untuk melihat signifikan ada atau tidaknya pengaruh masing-masing variabel independen terhadap variabel dependen:

Tabel 2. Koefisien Regresi Secara Parsial

\begin{tabular}{|c|c|c|c|c|c|}
\hline \multirow[t]{2}{*}{$\begin{array}{c}\text { Mod } \\
\text { el }\end{array}$} & \multicolumn{2}{|c|}{$\begin{array}{l}\text { Unstandardized } \\
\text { Coefficients }\end{array}$} & $\begin{array}{c}\text { Standardize } \\
d \\
\text { Coefficients }\end{array}$ & $t$ & Sig. \\
\hline & B & Std. Error & Beta & & \\
\hline $1 \quad$ (Constan & 2.295 & .225 & & 10.181 & .000 \\
\hline CDP & .329 & .081 & .505 & 4.053 & .000 \\
\hline
\end{tabular}

a Dependent Variable: Motivasi Kerja Karyawan 
Sumber: Hasil pengolahan data kuesioner

Persamaan regresinya diperoleh $Y=2.295+0.329 X$, yang mana: $Y=$ motivasi kerja karyawan; $X$ = sikap karyawan terhadap CDP. Persamaan tersebut dapat diartikan bahwa konstanta sebesar 2.295 menunjukkan apabila nilai dari sikap karyawan terhadap CDP adalah sama dengan nol ( $\mathrm{X}=0$ ), maka motivasi kerja karyawan benilai positif. Hal ini menunjukkan bahwa ada faktor lain selain sikap karyawan terhadap CDP yang belum terjelaskan yang memotivasi kerja karyawan. Setiap kenaikan atau penurunan motivasi kerja mampu mempengaruhi naik turunnya sikap karyawan terhadap CDP sebesar 32,9\%. Hubungan yang positif menunjukkan apabila sikap karyawan terhadap CDP semakin positif akan meningkatkan tingkat motivasi kerja karyawan, begitu pula apabila setiap penurunan sikap karyawan terhadap CDP semakin negatif, maka akan menurunkan tingkat motivasi kerja karyawan.

\section{Analisis Korelasi Sederhana}

Analisis korelasi Pearson digunakan untuk mengetahui ada tidaknya korelasi antar variabel. Hasil yang diperoleh membuktikan bahwa korelasi hubungan yang cukup tinggi antara variabel sikap karyawan terhadap CDP dengan motivasi kerja karyawan. Hal tersebut ditunjukkan dengan nilai tingkat korelasi (r) sebesar 0,505.

Tabel 3. Hasil Analisis Korelasi

\begin{tabular}{|c|c|c|c|}
\hline & & CDP & $\begin{array}{c}\text { Motivasi } \\
\text { Kerja }\end{array}$ \\
\hline \multirow[t]{3}{*}{ CDP } & $\begin{array}{c}\text { Pearson } \\
\text { Correlation }\end{array}$ & 1 & $.505(* *)$ \\
\hline & Sig. (2-tailed) & & .000 \\
\hline & N & 50 & 50 \\
\hline \multirow{3}{*}{$\begin{array}{c}\text { Motiv } \\
\text { asiKerj } \\
\text { a }\end{array}$} & $\begin{array}{l}\text { Pearson } \\
\text { Correlation }\end{array}$ & $.505\left(^{* *}\right)$ & 1 \\
\hline & Sig. (2-tailed) & .000 & \\
\hline & $\mathrm{N}$ & 50 & 50 \\
\hline
\end{tabular}

Uji Beda

Untuk mengetahui ada tidaknya perbedaan motivasi kerja karyawan antara yang sudah menerima CDP dengan karyawan yang belum menerima CDP digunakan the pairedobservation t test (Santoso 2001). Adapun hasil yang diperoleh terlihat pada tabel 4 di bawah ini:

Tabel 4. Pasangan Sampel Statistik

\begin{tabular}{|c|c|r|r|c|}
\hline CDP & Mean & $\mathrm{N}$ & $\begin{array}{c}\text { Std. } \\
\text { Deviation }\end{array}$ & $\begin{array}{c}\text { Std. Error } \\
\text { Mean }\end{array}$ \\
\hline Belum & 36.4000 & 25 & 3.81881 & .76376 \\
Sudah & 40.8000 & 25 & 3.66288 & .73258 \\
\hline
\end{tabular}

Sumber : Hasil pengolahan data kuesioner

Tabel 4 menunjukkan bahwa rata-rata nilai jawaban responden mengenai motivasi kerja mengalami kenaikan dari 36,4 menjadi 40,8. Hal tersebut dapat menyimpulkan bahwa memang ada kenaikan tingkat motivasi kerja karyawan antara yang sudah menerima CDP dengan yang belum menerima sebesar 4,4. Akan tetapi, hal itu tidak ditunjang oleh hasil 
koefisien korelasinya yang sangat kecil, yaitu sebesar 0,027 dan hasil tes pasangan sampel sebagaimana terlihat pada Tabel 5.

Tabel 5. Hasil Tes Pasangan Sampel

\begin{tabular}{|c|c|c|c|c|c|c|c|c|}
\hline \multirow{3}{*}{ CDP } & \multicolumn{5}{|c|}{ Perbedaan Dipasangkan } & \multirow[t]{2}{*}{$\dagger$} & \multirow[t]{2}{*}{$d f$} & \multirow[t]{2}{*}{$\begin{array}{l}\text { Sig. (2- } \\
\text { tailed) }\end{array}$} \\
\hline & \multirow[t]{2}{*}{ Mean } & \multirow[t]{2}{*}{$\begin{array}{c}\text { Std. } \\
\text { Deviatio } \\
\mathrm{n}\end{array}$} & \multirow[t]{2}{*}{$\begin{array}{l}\text { Std. } \\
\text { Error } \\
\text { Mean }\end{array}$} & \multicolumn{2}{|c|}{$\begin{array}{c}\text { 95\% Confidence } \\
\text { Interval of the } \\
\text { Difference }\end{array}$} & & & \\
\hline & & & & Lower & Upper & & & \\
\hline $\begin{array}{l}\text { belum } \\
\text { sudah }\end{array}$ & -4.40000 & 5.22015 & 1.04403 & -6.55477 & $\begin{array}{r}2.2452 \\
3\end{array}$ & $4.214^{-}$ & 24 & .000 \\
\hline
\end{tabular}

Sumber : Hasil pengolahan data kuesioner

Pada Tabel 5 di atas terlihat bahwa mean sebesar $-4,4$ dengan standar deviasi sebesar 5,2. Nilai $\dagger$ hitung $-4,214$. Sedangkan nilai sig. (2-tailed) sebesar $0.000<0,05$ sehingga dapat disimpulkan bahwa hipotesis tidak terbukti bahwa ada perbedaan motivasi kerja karyawan antara yang belum mendapat CDP dengan yang sudah mendapat CDP.

Analisis Pembahasan Efektivitas Pemberian CDP terhadap Motivasi Kerja Karyawan ShangriLa Hotel Surabaya

Pengukuran terhadap motivasi kerja berdasarkan pada teori yang dikemukakan oleh George dan Jones (2005: 175), yang meliputu arah perilaku (direction of behavior), tingkat usaha (level of effort), dan tingkat kegigihan (level of persistence). Ketiga unsur ini saling berkaitan dengan motivasi kerja karyawan. Hasil penelitian menunjukkan bahwa koefisien determinasi $\left(\mathrm{R}^{2}\right)$ diperoleh angka $25,5 \%$. Hal ini dapat diartikan bahwa besarnya persentase nilai variabel independen (sikap karyawan terhadap CDP) untuk menjelaskan variabel dependen (motivasi kerja karyawan) adalah sebesar 25,5\%, sedangkan sisanya $74,5 \%$ dijelaskan oleh variabel lain di luar variabel yang diteliti.

Hasil koefisien korelasi (r) diperoleh angka 0,505 atau 51\%. Hal itu berarti terdapat hubungan yang cukup tinggi antara variabel dependen dan variabel independen. Hl yang menyatakan "diduga pemberian CDP efektif dalam meningkatkan motivasi kerja karyawan Shangri-La Hotel Surabaya" dapat diterima dengan nilai persentase efektivitas sebesar $56 \%$. H2 yang menyatakan "Diduga ada perbedaan motivasi kerja karyawan Shangri-La Hotel Surabaya antara yang sudah menerima CDP dengan yang belum menerima CDP" ditolak karena hasil uji beda (the paired-observation t test) menyatakan bahwa nilai sig. (2-tailed) sebesar $0.000<0,05$. Karena ada faktor-faktor lain dalam hal motivasi kerja yang memotivasi karyawan yang belum mendapatkan CDP.

Berdasarkan wawancara yang dilakukan, karyawan juga tidak tertarik atau terdorong oleh karena besarnya nominal atau pun kemenarikan dari souvenir yang diberikan, namun juga terdorong oleh kebanggaan dan kepuasan kerja untuk mendapatkan Customer Delight Program, karena dengan mendapatkan Customer Delight Program dirinya akan dikenal atau diketahui kebanyakan orang karena namanya akan terpampang di notice board yang bisa dilihat oleh karyawan lain. Apabila dibandingkan dengan hasil penelitian sebelumnya yang menyatakan bahwa tingkat motivasi kerja karyawan di Shangri-La Hotel Surabaya tinggi. Hal tesebut dapat dibuktikan dengan persentase tingkat motivasi kerja yang tinggi sebesar 91\%. Dengan demikian terdapat keterkaitan antara keberadaan 
Shangri-La Academy Program dengan tingkat motivasi kerja karyawan Shangri-La Hotel Surabaya. Hal itu berarti terdapat dependensi yang besar antara motivasi kerja karyawan dan Shangri-La Academy Program. Adanya Shangri-La Academy Program efektif dalam meningkatkan motivasi kerja karyawan Shangri-La Hotel Surabaya karena ada kebanggaan ketika berhasil terpilih mengikuti program tersebut (Fandianto dan Sutanto 2012). Efektivitas implementasi Shangri-La Academy Program dapat menjadi acuan yang berharga bagi peningkatan efektivitas Customer Delight Program khususnya bagi karyawan yang belum pernah mendapatkannya.

\section{SIMPULAN}

Hasil distribusi penilaian efektivitas CDP menjelaskan bahwa hipotesis satu terbukti, yaitu pemberian CDP efektif dalam meningkatkan motivasi kerja karyawan Shangri-La Hotel Surabaya, hal tersebut didukung oleh penghitungan yang menggunakan persentase efektivitas yang menunjukan bahwa CDP tersebut efektif sebesar $56 \%$. Akan tetapi, ternyata tidak ada perbedaan keberadaan CDP bagi karyawan Shangri-La Hotel Surabaya, baik bagi yang sudah menerima ataupun yang belum menerima CDP. Hal ini diperkuat oleh hasil uji beda yang menyatakan bahwa nilai sig. (2-tailed) sebesar $0.000<0,05$. Bagi karyawan yang belum menerima CDP termotivasi oleh faktor-faktor lain yang belum diteliti.

\section{Saran}

Berdasarkan pada temuan dalam penelitian ini, maka saran yang dapat diajukan adalah sebagai berikut: Pihak hotel sebaiknya memperbesar jumlah nominal yang diterima dalam program CDP karena berdasarkan wawancara yang dilakukan sebanyak $60 \%$ dari responden mengatakan bahwa jumlah nominal yang diterima dalam CDP kurang memadai dan souvenir yang diberikan kurang menarik, sehingga karyawan tidak begitu tertarik dalam mendapatkan CDP. Melihat pentingnya CDP ini dalam lingkungan bekerja, maka pihak hotel sebaiknya mempertahankan atau meningkatkan program CDP dengan mengelolanya secara lebih baik lagi misalnya dengan memberikan keuntungankeuntungan yang lain kepada karyawan yang telah mendapatkannya. Melihat faktor keseriusan dalam bekerja menjadi salah satu faktor utama dalam memotivasi karyawan untuk mendapatkan program CDP. Oleh karena itu pihak hotel perlu untuk mempertahankan atau meningkatkan loyalitas karyawan agar bekerja dengan kualitas yang terbaik.

Disarankan untuk penelitian selanjutnya untuk meneliti lebih dalam lagi, karena ada beberapa faktor-faktor lain yang mempengaruhi motivasi kerja karyawan, misalnya: kesempatan jenjang karir.

\section{Daftar Referensi}

Becker, B.E., M.A. Huselid dan D. Ulrich. 2001. The HR Scorecard. Boston: Harvard Business School Press.

Bernardin, H.J. 2010. Human Resource Management: An Experiential Approach. $5^{\text {th }}$ International Ed. Singapore: McGraw-Hill Inc.

Cascio, W.F. 2005. Managing Human Resources: Productivity, Quality of Work Life, Profits. $7^{\text {th }}$ Ed. USA: McGraw-Hill/ Irwin.

Dessler, G. 2011 . Human Resource Management. 12 th Ed. New Jersey: Prentice Hall.

Fandianto, L. dan E.M. Sutanto. 2012. The Effectiveness Analysis of "Shangri-La Academy Program" on Employees' Work Motivation at Shangri-La Hotel Surabaya. Journal of Indonesian Economy and Business 27/3.

George, J.M. dan G.R. Jones. 2005. Essentials of Managing Organizational Behavior (4th Ed.). New Jersey: Upper Saddle River.

Handoko, T.H. 2001. Manajemen Personalia dan Sumber Daya Manusia. Yogyakarta: BPFE. 
Kuncoro, M. 2004. Metode Riset Untuk Bisnis dan Ekonomi. Surabaya: Erlangga.

Lawler, E.E. 2002. Pay Strategy: New Thinking for the New Millenium. Dalam Feris, G.R., et al. Human Resource Management. Upper Saddle River, NJ: Prentice Hall, pp. 310-316.

Milkovich, G.T. dan J.M. Newman. 2005. Compensation. USA: Irwin

Luthans, F. 2006. Organizational Behavior. $11^{\text {th }}$ Ed. New York: McGraw-Hill, Inc.

Mangkunegara, A.A.P. 2004. Manajemen Sumber Daya Manusia Perusahaan. Bandung: PT. Remaja Rosdakarya.

Ranupandjojo, H. dan S. Husnan. 2002. Manajemen Personalia, Yogyakarta: BPFE.

Robbins, S. P. 2009. Organizational Behaviour. 13 th Ed. New Jersey: McGraw-Hill, Inc.

Rynes, S.L. dan J.E. Bono. 2000. Psychological Research on Determinants of Pay. Dalam Rynes, S.L. dan B. Gerhart (Eds). Compensation in Organizations: Current Research and Practice. San Fransisco: Jossey-Bass. pp. 3-31.

Santoso, S. 2001. SPSS Statistik Parametrik. Jakarta: PT. Elex Media Komputindo.

Sastradipoera, K. 2004. Manajemen Sumber Daya Manusia. Bandung: Kappa Sigma.

Saydam, G. 2006. Built-In Training-Jurus Jitu Mengembangkan Profesionalisme SDM. Bandung: PT. Remaja Rosdakarya.

Schermerhorn, J.R. 2001. Manajemen. 5th Ed. Yogyakarta: Penerbit Andi Offset.

Shangri-La Hotels and Resort. (2010). Customer Delight Program Retrieved March 6, 2010, from: http://www.shangri-la.com.

Simamora, H. 2003. Manajemen Sumber Daya Manusia. Jakarta: PT. Gramedia Pustaka Utama.

Sugianto, E. 2003. Pengantar Akomodasi dan Restoran. Jakarta: PT. Gramedia Pustaka Utama.

Sugiyono. 2004. Metode Penelitian Bisnis. Bandung: CV Alfabeta. 